Check for updates

Cite this: RSC Adv., 2017, 7, 31115

\title{
New prenylxanthones, polyketide hemiterpenoid pigments from the endophytic fungus Emericella sp. XL029 and their anti-agricultural pathogenic fungal and antibacterial activities $\uparrow$
}

\author{
Xia Wu, ${ }^{a}$ Li-Zhen Fang, ${ }^{c}$ Feng-Lou Liu, ${ }^{d}$ Xue-Jiao Pang, ${ }^{a}$ Hai-Li Qin, ${ }^{a}$ Ting Zhao, ${ }^{a}$ \\ Lu-Lin Xu, ${ }^{a}$ Deng-Feng Yang ${ }^{* b}$ and Xiao-Long Yang (DD *a
}

\begin{abstract}
Four new prenylxanthones (1-4) together with five known compounds (5-9) were isolated from the solidsubstrate fermentation culture of Emericella sp. XL029 associated with the leaves of Panax notoginseng. Their structures and relative configurations were elucidated by extensive spectroscopic analysis and comparison of NMR data to those of known compounds. The anti-agricultural pathogenic fungal and antibacterial activities of all isolated compounds were evaluated against eight agricultural pathogenic fungi and nine human pathogenic bacteria. The anti-agricultural pathogenic fungal assay indicated that compounds 1, 2, 4, 8 and 9 displayed significant activity against Drechslera maydis with MIC value of 25

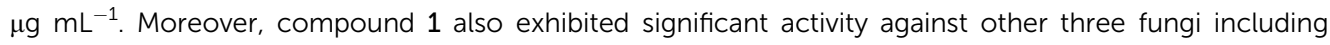
Rhizoctonia cerealis, Fusarium oxysporum and Physalospora piricola, and compounds 4 and 9 against Rhizoctonia cerealis with MIC value of $25 \mu \mathrm{g} \mathrm{mL} \mathrm{L}^{-1}$. Compound 5 only demonstrated significant activity against Physalospora piricola with MIC value of $25 \mu \mathrm{g} \mathrm{mL}{ }^{-1}$. Further antibacterial activity tests revealed that compounds 1-9 showed significant antibacterial activity against all tested Gram-positive (except for drug resistant Staphylococcus aureus) and Gram-negative bacteria with MIC values ranging from 12.5 to $50 \mu \mathrm{g} \mathrm{mL}{ }^{-1}$. While only compounds 1,4 and 9 displayed moderate activity against drug resistant Staphylococcus aureus with MIC value of $50 \mu \mathrm{gL}^{-1}$.
\end{abstract}

Received 28th April 2017 Accepted 25th May 2017 DOI: $10.1039 / c 7 r a 04762 b$

rsc.li/rsc-advances common in plants (mainly in Clusiaceae, Gentianaceae, Moraceae, and Polygalaceae families) and fungi. Due to their unique structures and significant therapeutic potential, they have the promising potential applications in acting as lead compounds for new generations of anticancer, antibacterial, immunomodulatory, antidiabetic, and antiobesity agents, etc. ${ }^{4}$

Plant endophytic fungi inhabiting the normal tissues of host plants without causing apparent pathogenic symptoms are well known producers of novel secondary metabolites with outstanding potential for generating novel therapeutic leads. ${ }^{5}$ The fungal genus Emericella, as the major group of fungi, has been reported to be the promising resources for secreting novel bioactive prenylxanthones, such as E. rugulosa, E. variecolor, $E$. nidulans, E. sp. SCSIO 05240, and E. striata.$^{6-14}$ Furthermore, fungi of the Emericella species are the sexual states of Aspergillus species, the perfect states of Aspergillus, has been the source of various classes of bioactive compounds. , $^{8,23,24}$

During our studies in searching for novel bioactive compounds from plant endophytic fungi, we have isolated the interesting pigment-producing fungal strain (XL029) associated with the leaves of Panax notoginseng, belonging to the genus Emericella. The present study was undertaken to search for novel pigments from the solid-substrate fermentation culture of 


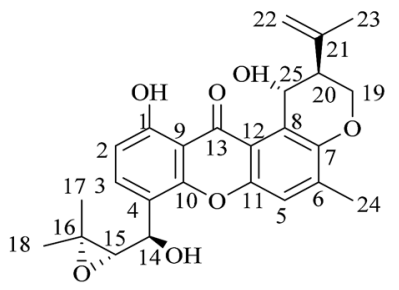

1<smiles>C=C(C)[C@@H]1COc2c(C)cc3oc4c([C@H](O)C(O)C(C)(C)Cl)ccc(O)c4c(=O)c3c2C1</smiles>

3<smiles>C=C(C)[C@@H]1COc2c(C)cc3oc4c(C[C@H](O)C(C)(C)O)ccc(O)c4c(=O)c3c2[C@@H]1O</smiles>

5<smiles>C=C(C)[C@H]1COc2c(C)cc3oc4c(C[C@@H](O)C(C)(C)Cl)ccc(O)c4c(=O)c3c2C1C</smiles><smiles>CCC/C=C/C=C/CCc1cc(O)c([C@@H]2O[C@H](CO)[C@@H](O)[C@H](O)[C@H]2O)c(O)c1C(=O)OC</smiles>

9

Fig. 1 Structures of compounds 1-9

Emericella sp. XL029, which led to the isolation of nine compounds (1-9) including four new ones (1-4) (Fig. 1), seven of them belonging to prenylxanthones. In this paper, the isolation, structure elucidation and biological activities of these compounds are described.

\section{Results and discussion}

Compound 1 was obtained as a yellow powder. The molecular formula was determined to be $\mathrm{C}_{25} \mathrm{H}_{26} \mathrm{O}_{7}$ based on the HRESIMS at $m / z 437.1586\left([\mathrm{M}-\mathrm{H}]^{-}\right.$, calcd 437.1606), implying the presence of thirteen degrees of unsaturation. The IR spectrum exhibited absorptions of hydroxyl $\left(3446 \mathrm{~cm}^{-1}\right)$, aromatic ketone
(1643 $\mathrm{cm}^{-1}$ ) functionalities. The ${ }^{1} \mathrm{H}$ NMR (Table 1) and HSQC spectra indicated the presence of three aromatic protons $\left[\delta_{\mathrm{H}}\right.$ 7.22 (s, H-5), 6.85 (d, J=8.6 Hz, H-2), and 7.83 (d, $J=8.6 \mathrm{~Hz}, \mathrm{H}-$ $3)]$, four tertiary methyls $\left[\delta_{\mathrm{H}} 1.31(\mathrm{~s}, \mathrm{H}-17), 1.50(\mathrm{~s}, \mathrm{H}-18), 1.86(\mathrm{~s}\right.$, $\mathrm{H}-23$ ), and 2.36 (s, H-24)], two methylenes including one oxygennated $\left[\delta_{\mathrm{H}} 4.43(\mathrm{dd}, J=3.2,10.9, \mathrm{H}-19 \mathrm{a}), 4.35\right.$ (dd, $J=3.0$, $10.9, \mathrm{H}-19 \mathrm{~b})]$ and one olefinic signal $\left[\delta_{\mathrm{H}} 4.82(\mathrm{~s}, \mathrm{H}-22 \mathrm{a}), 4.60(\mathrm{~s}\right.$, $\mathrm{H}-22 \mathrm{~b})]$, four methine signals $\left[\delta_{\mathrm{H}} 5.14(\mathrm{~d}, J=7.4, \mathrm{H}-14), 3.11(\mathrm{~d}, J\right.$ $=7.6, \mathrm{H}-15), 2.74(\mathrm{~d}, J=2.8, \mathrm{H}-20)$, and $5.43(\mathrm{t}, J=3.1,6.2, \mathrm{H}-$ 25)] as well as two exchangeable proton signals at $\delta_{\mathrm{H}} 12.80$ (s, 1$\mathrm{OH})$ and $4.97(\mathrm{~d}, J=3.9,25-\mathrm{OH})$. The ${ }^{13} \mathrm{C}$ NMR and DEPT spectra (Table 1) revealed the presence of 25 carbons, which were assigned as four methyls, two methylenes (one oxygenated and one olefinic carbon), seven methines (including aromatic and oxygenated carbons), and twelve nonprotonated carbons (including one ketone carbonyl). The COSY correlations (H-19/ $\mathrm{H}-20 / \mathrm{H}-25$, corresponding to $\mathrm{OCHCHCH}_{2} \mathrm{O}$ spin system) and the key HMBC correlations (Fig. 2) from $\mathrm{H}-19$ to $\mathrm{C}-7$, from $\mathrm{H}-20$ to $\mathrm{C}-8$, and from $\mathrm{H}-25$ to $\mathrm{C}-7$ and C-12 suggested the presence of dihydropyran ring, which was fused to an aromatic unit at C-7 and C-8. The isopropenyl moiety was deduced by the key HMBC correlations from $\mathrm{H}-22$ to C-20, C-21 and C-23, which was connected to the pyran ring at C-20. A comprehensive analysis of 1D NMR data along with above evidences revealed the structure of 1 was mostly identical to 14-methoxytajixanthone, ${ }^{13}$ previously reported from the fungus Emericella rugulosa, except for the absence of methoxy group at C-14 and the presence of hydroxyl group, which was further confirmed by HMBC experiments and molecular weight. The relative configurations of all chiral centers in 1 were determined to be $14 R^{*}, 15 S^{*}, 20 S^{*}$, $25 R^{*}$, respectively, by comparison of the coupling constants, NMR data with those of reported tajixanthone derivatives, ${ }^{\mathbf{1 2 - 1 4}}$ and the experimental optical rotation data $[\alpha]_{\mathrm{D}}^{25}-59^{\circ}(c 0.183$, $\mathrm{CHCl}_{3}$ ) with those of related known compound 14methoxyltajixanthone-25-acetate $[\alpha]_{\mathrm{D}}^{20}-38^{\circ}$ (c $0.1, \mathrm{CHCl}_{3}$ ), which was further confirmed by the NOE correlations (Fig. 3) of $\mathrm{H}_{\mathrm{a}}-19$ with $\mathrm{H}_{\mathrm{b}}-22, \mathrm{H}-23$, and $\mathrm{H}-25, \mathrm{H}_{\mathrm{b}}-19$ with $\mathrm{H}-20$ and $\mathrm{OH}-25$, $\mathrm{H}-25$ with $\mathrm{H}_{\mathrm{b}}-22$ and $\mathrm{H}-23$. Thus, compound 1 was determined as 14-hydroxyltajixanthone.

Compound 2 was obtained as a yellow powder. The molecular formula was determined to be $\mathrm{C}_{25} \mathrm{H}_{28} \mathrm{O}_{8}$ by the HRESIMS at $m / z 479.1684\left([\mathrm{M}+\mathrm{Na}]^{+}\right.$, calcd 479.1676), suggesting twelve degrees of unsaturation. Analysis of its 1D NMR spectroscopic data (Table 1) revealed the presence of 25 carbons, which were assigned as four methyls, two methylenes, seven methines, and twelve nonprotonated carbons. By comparison of its NMR spectra with those of $\mathbf{1}$ revealed that compound $\mathbf{2}$ has the same tajixanthone type skeleton, ${ }^{\mathbf{1 4 , 1 7 , 1 8}}$ and its NMR data were almost identical to those of $\mathbf{1}$, obviously differing only in the chemical shifts at C-15 and C-16. The carbon chemical shifts at C-15 $\left(\delta_{\mathrm{C}}\right.$ 77.2) and C-16 $\left(\delta_{\mathrm{C}} 73.9\right)$ were shifted significantly downfield in 2 compared to 1 [C-15 $\left(\delta_{\mathrm{C}} 67.6\right)$ and $\left.\mathrm{C}-16\left(\delta_{\mathrm{C}} 60.5\right)\right]$, indicating that the 14,15-epoxy ring in 1 was opened to form 14,15-diol moiety in 2 , which was further supported by evidence deduced from its molecular formula that has one more oxygen and two hydrogen atoms (18 mass units difference) than 1. It suggested that compound $\mathbf{2}$ is the epoxide ring-opening product of $\mathbf{1}$. The 
Table $1{ }^{1} \mathrm{H}$ and ${ }^{13} \mathrm{C}$ NMR data for compounds for $1-4$

\begin{tabular}{|c|c|c|c|c|c|c|c|c|}
\hline \multirow[b]{2}{*}{ No. } & \multicolumn{2}{|l|}{$\mathbf{1}^{a}$} & \multicolumn{2}{|l|}{$2^{a}$} & \multicolumn{2}{|l|}{$3^{a}$} & \multicolumn{2}{|l|}{$4^{a}$} \\
\hline & $\delta_{\mathrm{C}}$, type & $\delta_{\mathrm{H}}(J$ in $\mathrm{Hz})$ & $\delta_{\mathrm{C}}$, type & $\delta_{\mathrm{H}}(J$ in $\mathrm{Hz})$ & $\delta_{\mathrm{C}}$, type & $\delta_{\mathrm{H}}(J$ in $\mathrm{Hz})$ & $\delta_{\mathrm{C}}$, type & $\delta_{\mathrm{H}}(J$ in $\mathrm{Hz})$ \\
\hline 1 & 161.7, C & & $160.5, \mathrm{C}$ & & 161.2, C & & $160.4, \mathrm{C}$ & \\
\hline 2 & 110.6, CH & $6.85, \mathrm{~d}(8.6)$ & 109.9, CH & $6.79, \mathrm{~d}(8.5)$ & $110.2, \mathrm{CH}$ & $6.83, \mathrm{~d}(8.4)$ & 109.9, CH & $6.76, \mathrm{~d}(8.3)$ \\
\hline 3 & 135.1, CH & $7.83, \mathrm{~d}(8.6)$ & 135.1, CH & $7.84, \mathrm{~d}(8.5)$ & $134.5, \mathrm{CH}$ & $7.81, \mathrm{~d}(8.5)$ & 138.1, CH & $7.52, \mathrm{~d}(8.3)$ \\
\hline 4 & $117.8, \mathrm{C}$ & & 119.4, C & & 119.7, C & & 116.1, C & \\
\hline 5 & $118.9, \mathrm{CH}$ & $7.22, \mathrm{~s}$ & $118.9, \mathrm{CH}$ & $7.15, \mathrm{~s}$ & $119.0, \mathrm{CH}$ & $7.23, \mathrm{~s}$ & $119.2, \mathrm{CH}$ & $7.23, \mathrm{~s}$ \\
\hline 6 & $138.8, \mathrm{C}$ & & 138.5, C & & 138.7, C & & 138.7, C & \\
\hline 7 & 149.8, C & & 149.6, C & & 149.7, C & & 149.4, C & \\
\hline 8 & 121.3, C & & $120.9, \mathrm{C}$ & & 121.2, C & & 121.6, C & \\
\hline 9 & 109.0, C & & 108.6, C & & $108.8, \mathrm{C}$ & & 109.2, C & \\
\hline 10 & 152.1, C & & 151.0, C & & 151.2, C & & 153.1, C & \\
\hline 11 & $151.8, \mathrm{C}$ & & 151.7, C & & 151.9, C & & 151.7, C & \\
\hline 12 & 116.9, C & & 116.7, C & & 116.9, C & & 116.7, C & \\
\hline 13 & 184.2, C & & 184.1, C & & 184.2, C & & 184.2, C & \\
\hline 14 & $66.5, \mathrm{CH}$ & $5.14, \mathrm{~d}(7.4)$ & $66.4, \mathrm{CH}$ & $5.62, \mathrm{~s}$ & $65.3, \mathrm{CH}$ & 5.68, brs & $31.9, \mathrm{CH}_{2}$ & $\begin{array}{l}3.19 \text {, brd }(14.0) ; \\
2.68, \text { dd } \\
(10.5,14.0)\end{array}$ \\
\hline 15 & $67.6, \mathrm{CH}$ & $3.11, \mathrm{~d}(7.6)$ & $77.2, \mathrm{CH}$ & $3.44, \mathrm{~s}$ & 79.6, CH & 3.73, brd $(4.4)$ & 77.7, CH & 3.72 , brd (10.2) \\
\hline 16 & $60.5, \mathrm{C}$ & & $73.9, \mathrm{C}$ & & $74.3, \mathrm{C}$ & & $72.9, \mathrm{C}$ & \\
\hline 17 & $24.8, \mathrm{CH}_{3}$ & $1.31, \mathrm{~s}$ & $27.0, \mathrm{CH}_{3}$ & $1.32, \mathrm{~s}$ & $29.4, \mathrm{CH}_{3}$ & $1.79, \mathrm{~s}$ & 23.5, $\mathrm{CH}_{3}$ & $1.36, \mathrm{~s}$ \\
\hline 18 & $19.7, \mathrm{CH}_{3}$ & $1.50, \mathrm{~s}$ & $26.0, \mathrm{CH}_{3}$ & $1.50, \mathrm{~s}$ & $29.0, \mathrm{CH}_{3}$ & $1.78, \mathrm{~s}$ & 26.6, $\mathrm{CH}_{3}$ & $1.41, \mathrm{~s}$ \\
\hline 19 & 64.7, $\mathrm{CH}_{2}$ & $\begin{array}{l}4.43, \mathrm{dd} \\
(3.2,10.9) ; \\
4.35, \mathrm{dd} \\
(3.0,10.9)\end{array}$ & $64.5, \mathrm{CH}_{2}$ & $\begin{array}{l}4.39, \mathrm{dd} \\
(3.0,10.9) ; \\
4.30, \mathrm{dd} \\
(2.7,10.9)\end{array}$ & 64.6, $\mathrm{CH}_{2}$ & $\begin{array}{l}4.43 \text {, dd }(2.6,10.9) \\
4.35 \text {, dd }(3.0,10.9)\end{array}$ & $64.0, \mathrm{CH}_{2}$ & $\begin{array}{l}4.47, \mathrm{dd} \\
(2.1,10.1) ; \\
4.33, \mathrm{dd} \\
(10.4,11.9)\end{array}$ \\
\hline 20 & $44.9, \mathrm{CH}$ & $2.74, \mathrm{~d}(2.8)$ & $44.7, \mathrm{CH}$ & 2.68 , brs & $44.9, \mathrm{CH}$ & $2.74, \mathrm{~d}(2.4)$ & $43.9, \mathrm{CH}$ & 2.55, brd (11.8) \\
\hline 21 & $142.5, \mathrm{C}$ & & $142.3, \mathrm{C}$ & & $142.5, \mathrm{C}$ & & 142.1, C & \\
\hline 22 & $112.4, \mathrm{CH}_{2}$ & $4.82, \mathrm{~s} ; 4.60, \mathrm{~s}$ & $112.3, \mathrm{CH}_{2}$ & $4.78, \mathrm{~s} ; 4.55, \mathrm{~s}$ & $112.3, \mathrm{CH}_{2}$ & $4.82, \mathrm{~s} ; 4.59, \mathrm{~s}$ & 111.6, $\mathrm{CH}_{2}$ & $5.07, \mathrm{~s} ; 4.78, \mathrm{~s}$ \\
\hline 23 & $22.5, \mathrm{CH}_{3}$ & $1.86, \mathrm{~s}$ & 22.4, $\mathrm{CH}_{3}$ & $1.82, \mathrm{~s}$ & $22.5, \mathrm{CH}_{3}$ & $1.86, \mathrm{~s}$ & $22.5, \mathrm{CH}_{3}$ & $1.99, \mathrm{~s}$ \\
\hline 24 & $17.5, \mathrm{CH}_{3}$ & $2.36, \mathrm{~s}$ & $17.3, \mathrm{CH}_{3}$ & $2.32, \mathrm{~s}$ & $17.5, \mathrm{CH}_{3}$ & $2.36, \mathrm{~s}$ & $17.5, \mathrm{CH}_{3}$ & $2.37, \mathrm{~s}$ \\
\hline 25 & $63.3, \mathrm{CH}$ & $5.43, \mathrm{t}(3.1,6.2)$ & 63.1, $\mathrm{CH}$ & 5.38, brs & $63.2, \mathrm{CH}$ & 5.41 , brs & $61.2, \mathrm{CH}$ & $5.48, \mathrm{t}(3.2,5.8)$ \\
\hline $\mathrm{OH}-1$ & & $12.80, \mathrm{~s}$ & & $12.59, \mathrm{~s}$ & & $12.66, \mathrm{~s}$ & & $12.60, \mathrm{~s}$ \\
\hline $\mathrm{OH}-14$ & & & & 2.68, brs & & 3.07, brs & & \\
\hline OH-15 & & & & $2.68, \mathrm{brs}$ & & $3.07, \mathrm{brs}$ & & 2.21 , brs \\
\hline OH-16 & & & & & & & & $1.65, \mathrm{brs}$ \\
\hline $\mathrm{OH}-25$ & & $4.97, \mathrm{~d}(3.9)$ & & $5.13, \mathrm{~d}(3.3)$ & & $4.98, \mathrm{~d}(3.8)$ & & $4.54, \mathrm{~d}(3.3)$ \\
\hline
\end{tabular}

relative configurations of 2 were assigned as $14 R^{*}, 15 S^{*}, 20 S^{*}$, $25 R^{*}$, respectively, the same as those of 1 , by comparison of the ${ }^{1} \mathrm{H}$ and ${ }^{13} \mathrm{C}$ NMR spectroscopic data and optical rotation value with those of 1, and further confirmed by the NOESY experiment (Fig. 3). Thus, compound 2 was determined as 14hydroxyltajixanthone hydrate.

Compound 3 was obtained as a yellow powder. The molecular formula was determined to be $\mathrm{C}_{25} \mathrm{H}_{27} \mathrm{ClO}_{7}$ by the HRESIMS at $m / z$ 473.1364 $\left([\mathrm{M}-\mathrm{H}]^{-}\right.$, calcd 473.1373), implying the presence of twelve degrees of unsaturation. Analysis of its ${ }^{1} \mathrm{H}$ and ${ }^{13} \mathrm{C}$ NMR spectroscopic data (Table 1 ) suggested that compound 3 also has the tajixanthone type skeleton, and its NMR data were almost identical to those of co-isolated known compound 15chlorotajixanthone hydrate (7), ${ }^{12}$ differing only in the chemical shifts at C-14. The carbon chemical shifts at C-14 $\left[\delta_{\mathrm{C}} 65.3(\mathrm{~d})\right]$ was shifted significantly downfield in 3 compared to $7\left[\delta_{\mathrm{C}} 31.9\right.$ (t)], indicating that the hydroxyl group was substituted at C-14 in 3, which was confirmed by HMBC correlations (Fig. 2) and its molecular formula that has one more oxygen atom than 7 . The relative configurations of all chiral centers in $\mathbf{3}$ are the same as those of 2 , by comparison of the coupling constants, 1D NMR, NOESY data and the experimental optical rotation data $[\alpha]_{\mathrm{D}}^{24}-53^{\circ}\left(c 0.167, \mathrm{CHCl}_{3}\right)$ with those of compound $2[\alpha]_{\mathrm{D}}^{24}-40^{\circ}$ (c $0.1, \mathrm{CHCl}_{3}$ ). Finally, compound 3 was established as 14hydroxyl-15-chlorotajixanthone hydrate.

Compound 4 was isolated as a yellow needle crystal with the same molecular formula $\mathrm{C}_{25} \mathrm{H}_{28} \mathrm{O}_{7}$ as that of co-isolated known compound $5,{ }^{12}$ on the basis of HRESIMS peak at $\mathrm{m} / \mathrm{z} 463.1720$ $\left([\mathrm{M}+\mathrm{Na}]^{+}\right.$, calcd 463.1727), suggesting twelve degrees of unsaturation. The ${ }^{13} \mathrm{C}$ NMR spectrum of 4 , which displayed 25 carbon signals analyzing by DEPT and HSQC data, indicated the presence of four methyls, three methylenes, six methines, and twelve quaternary carbons. Comparison of the NMR spectroscopic data of $\mathbf{4}$ with compound 5 revealed that both have the same planar structures, which further confirmed by HMBC correlations. It is suggested that the relative configurations of 4 


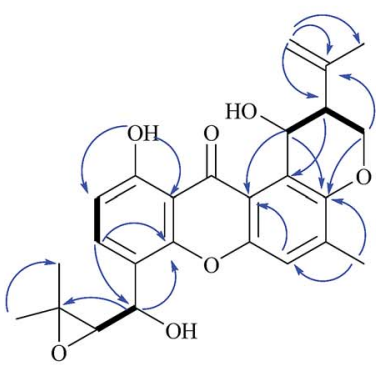

1

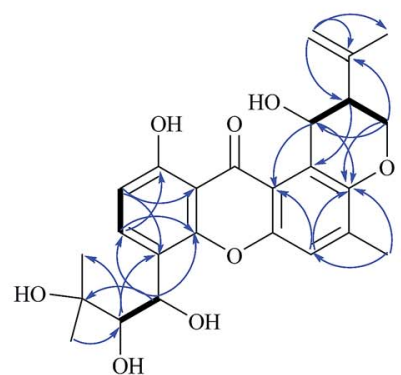

2

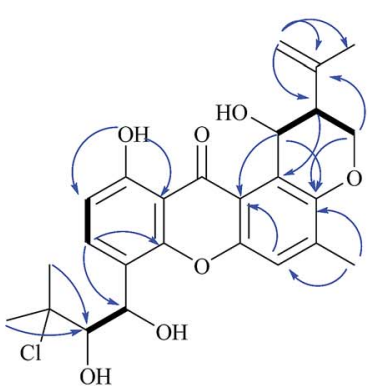

3

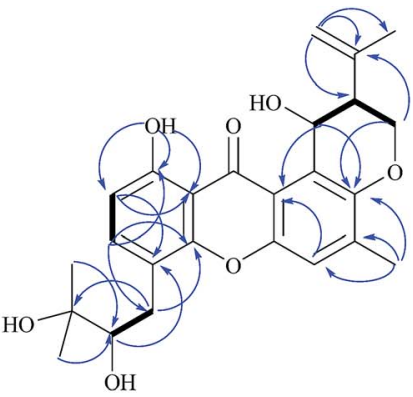

4

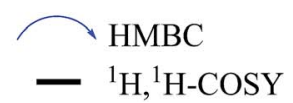

Fig. 2 Key HMBC and ${ }^{1} \mathrm{H},{ }^{1} \mathrm{H}$-COSY correlations of compounds $1-4$.

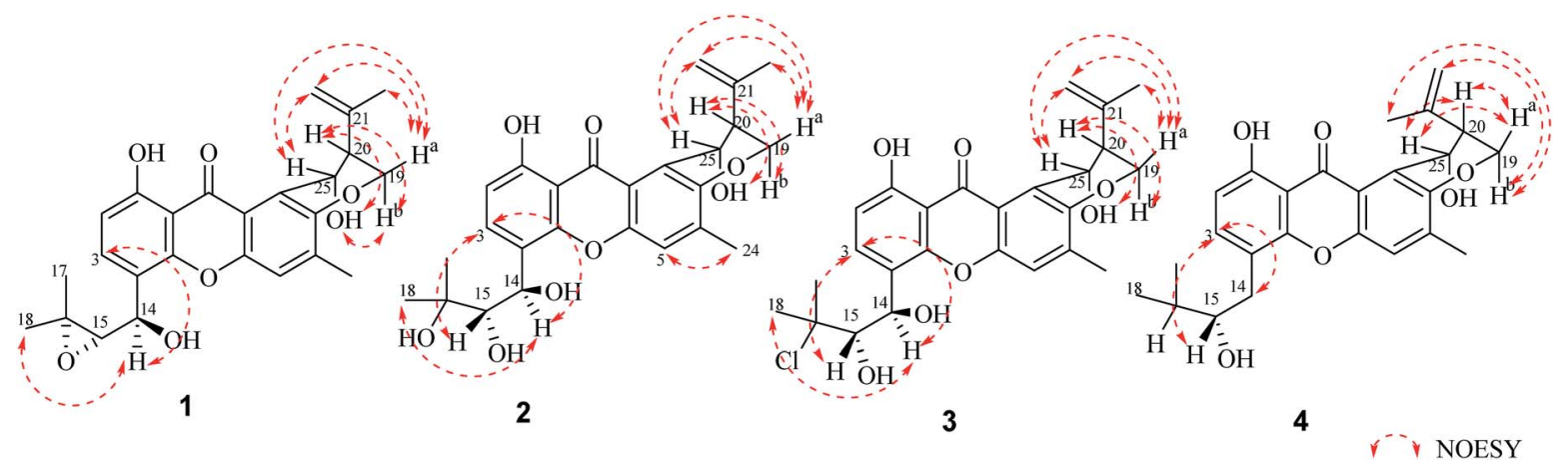

Fig. 3 Key NOESY correlations of compounds 1-4.

is different from those of $\mathbf{5}$, supported by evidence from their opposite optical rotation data [compound $4,[\alpha]_{\mathrm{D}}^{25}+61^{\circ}(c 0.1$, $\left.\mathrm{CHCl}_{3}\right)$; compound $\left.5,[\alpha]_{\mathrm{D}}^{25}-74^{\circ}\left(c 0.1, \mathrm{CHCl}_{3}\right)\right]$. The relative configuration of C-15 was assigned as $S^{*}$, the same as that of 5 , deducing from the similar carbon and proton chemical shifts, and protons coupling constants. Further comparison of the ${ }^{13} \mathrm{C}$ NMR data with those of 5 indicated the chemical shifts at C-8, C19, C-20, C-22 and C-25 are obviously different from those of 5, suggesting that the relative configurations at C-20 and C-25 are different in these two compounds. Finally, the relative configurations at C-20 and C-25 were determined to be $R^{*}, R^{*}$, by the NOESY correlations of $\mathrm{H}_{\mathrm{b}}-19$ with $\mathrm{H}_{\mathrm{b}}-22, \mathrm{H}-23, \mathrm{H}_{\mathrm{a}}-19$ with $\mathrm{H}-20$, H-25 with H-20 (Fig. 3), the same as related compound epishamixanthone reported from Aspergillus rugulosus, ${ }^{19}$ and the configurations were further confirmed by a single-crystal X-ray diffraction analysis (Fig. 4). Thus, compound 4 was epitajixanthone hydrate.

Five known compounds (5-9) including three prenylxanthones derivatives (5-7) were also isolated and identified as tajixanthone hydrate (5), ${ }^{12}$ 14-methoxyltajixanthone-25acetate (6), ${ }^{18}$ and 15-chlorotajixanthone hydrate (7), ${ }^{12}$ questin $(\mathbf{8}),{ }^{20}$ and carnemycin $\mathrm{B}(\mathbf{9}),{ }^{21}$ respectively, based on the comparison of their spectroscopic data and optical rotation data with those reported in the literature. Moreover, the melting points of $5\left(174-175^{\circ} \mathrm{C}\right), 6\left(180-181^{\circ} \mathrm{C}\right), 7\left(174-175^{\circ} \mathrm{C}\right), 8(298-$ $\left.300{ }^{\circ} \mathrm{C}\right)$, and $9\left(102-112^{\circ} \mathrm{C}\right)$ were almost agreement with those of the known compounds. ${ }^{12,14,20,21}$

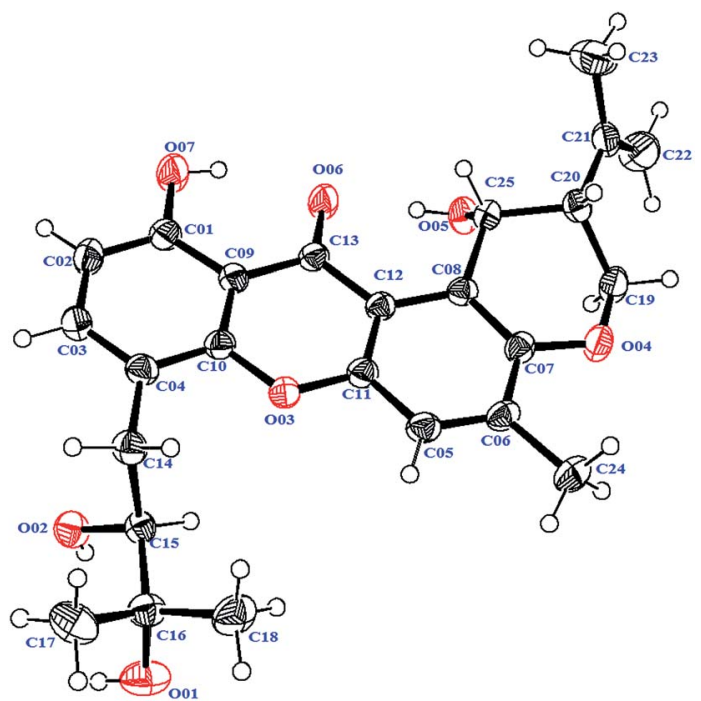

Fig. 4 ORTEP drawing of the compound 4. 
<smiles>C=C(C)[C@@H]1COc2c(C)cc3oc4c(CC=C(C)C)ccc(O)c4c(=O)c3c2[C@H]1O</smiles>

shamixanthone<smiles>C=C(C)[C@H]1COc2c(C)cc3oc4c(C[C@@H]5O[C@H]5C(C)(C)C)ccc(O)c4c(=O)c3c2[C@H]1O</smiles>

tajixanthone

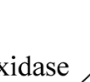
Haloperoxidase
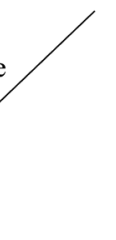

Hydoxylase<smiles>C=C(C)[C@@H]1COc2c(C)cc3oc4c(C[C@H](O)C(C)(C)Cl)ccc(O)c4c(=O)c3c2[C@@H]1O</smiles>

Hydroxylase<smiles>C=C(C)[C@@H]1COc2c(C)cc3oc4c([C@H](O)[C@H](O)C(C)(C)Cl)ccc(O)c4c(=O)c3c2[C@@H]1O</smiles>

3<smiles>C=C(C)[C@H]1COc2c(C)cc3oc4c([C@H](O)[C@H](O)C(C)(C)O)ccc(O)c4c(=O)c3c2[C@@H]1O</smiles>

2<smiles>C=C(C)[C@H]1COc2c(C)cc3oc4c([C@H](O)[C@@H]5O[C@H]5C)ccc(O)c4c(=O)c3c2[C@H]1O</smiles><smiles>[Y]C(I)[14C]([14CH3])[14CH3]</smiles><smiles>C=C(C)[C@@H]1COc2c(C)cc3oc4c([C@H](O)[C@@H]5OC5(C)C)ccc(O)c4c(=O)c3c2[C@H]1C(=O)O</smiles>

6

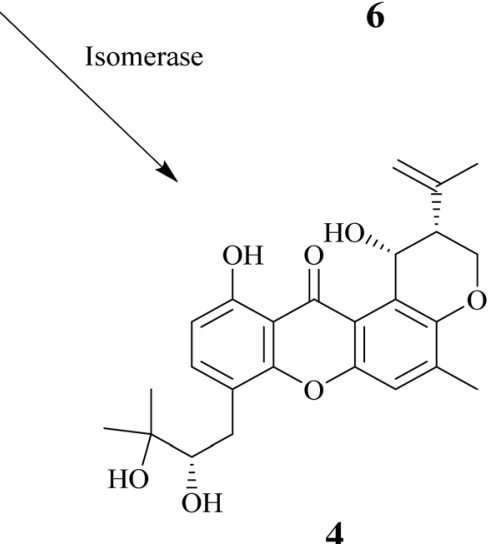

Scheme 1 The formation of compounds 1-7 derived from tajixanthone and shamixanthone.

Table 2 Antifungal activity of compounds 1-9 (MIC, $\left.\mu \mathrm{g} \mathrm{mL})^{-1}\right)^{a}$

\begin{tabular}{|c|c|c|c|c|c|c|c|c|}
\hline Compounds & $\begin{array}{l}R . \\
\text { solani }\end{array}$ & R. cerealis & $\begin{array}{l}D . \\
\text { maydis }\end{array}$ & F. oxysporum & S. sclerotiorum & $\begin{array}{l}\text { C. } \\
\text { fimbriata }\end{array}$ & $\begin{array}{l}\text { F. oxysporum } \\
\text { f. sp. vasinfectum }\end{array}$ & P. piricola \\
\hline 1 & 50 & 25 & 25 & 25 & 50 & 50 & 50 & 25 \\
\hline 2 & 100 & 50 & 25 & 50 & 100 & 100 & 100 & 50 \\
\hline 3 & $>100$ & 50 & 100 & $>100$ & 100 & $>100$ & $>100$ & 50 \\
\hline 4 & $>100$ & 25 & 25 & $>100$ & 100 & $>100$ & $>100$ & 50 \\
\hline 5 & 100 & 50 & 100 & 100 & $>100$ & 100 & 100 & 25 \\
\hline 6 & 100 & 50 & 50 & 50 & 100 & 100 & 100 & 50 \\
\hline 7 & 100 & 50 & 100 & 100 & $>100$ & $>100$ & $>100$ & 50 \\
\hline 8 & $>100$ & 50 & 25 & 50 & $>100$ & $>100$ & $>100$ & 50 \\
\hline 9 & 50 & 25 & 25 & 50 & 50 & 100 & 50 & 50 \\
\hline Ketoconazole & 6.25 & 3.12 & 1.56 & 3.12 & 3.12 & 12.50 & 6.25 & 3.12 \\
\hline
\end{tabular}

${ }^{a} \mathrm{MIC}-$ minimum inhibitory concentrations. 
Table 3 Antibacterial activity of compounds 1-9 (MIC, $\left.\mu \mathrm{g} \mathrm{mL}^{-1}\right)^{a}$

\begin{tabular}{|c|c|c|c|c|c|c|c|c|c|}
\hline \multirow[b]{2}{*}{ Compounds } & \multicolumn{5}{|c|}{ Gram-positive bacteria } & \multirow[b]{2}{*}{$\begin{array}{l}\text { Drug resistant } \\
\text { S. aureus }\end{array}$} & \multicolumn{3}{|c|}{ Gram-negative bacteria } \\
\hline & M. luteus & $\begin{array}{l}S . \\
\text { aureus }\end{array}$ & B. megaterium & B. anthracis & $\begin{array}{l}\text { B. paratyphosum } \\
\text { B }\end{array}$ & & P. aeruginosa & E. coli & E. aerogenes \\
\hline 1 & 25 & 25 & 12.5 & 12.5 & 12.5 & 50 & 50 & 50 & 25 \\
\hline 2 & 25 & 25 & 25 & 25 & 25 & $>100$ & 50 & 50 & 50 \\
\hline 3 & 25 & 25 & 25 & 25 & 25 & $>100$ & 50 & 50 & 50 \\
\hline 6 & 25 & 25 & 12.5 & 25 & 25 & $>100$ & 50 & 50 & 50 \\
\hline 7 & 50 & 25 & 12.5 & 50 & 25 & $>100$ & 50 & 50 & 50 \\
\hline 8 & 25 & 25 & 12.5 & 12.5 & 25 & $>100$ & 50 & 50 & 50 \\
\hline 9 & 25 & 25 & 12.5 & 25 & 25 & 50 & 50 & 50 & 50 \\
\hline Ciprofloxacin & 3.12 & 3.12 & 1.56 & 1.56 & 3.12 & 6.25 & 6.25 & 6.25 & 3.12 \\
\hline
\end{tabular}

In this study, nine compounds including four new ones were isolated from Emericella sp. XL029, eight of them (1-8) are pigments. Among these compounds, seven pigments (1-7) have tajixanthone type skeleton, the same as previously reported compounds tajixanthone and shamixanthone which has been confirmed to be derived through ring cleavage of an octaketidederived anthraquinone with introduction of two dimethylallyl moieties by isotopic labelling experiments. ${ }^{22}$ It is suggested that the formation of compounds 1-7 were derived from the tajixanthone biosynthetic pathway through various modifications, such as hydroxylation, oxidation, chlorination, acetylation, and isomerization (Scheme 1).

All isolates (1-9) were tested for their anti-agricultural pathogenic fungal activity on eight agricultural pathogenic fungi, namely, $R$. solani, $R$. cerealis, $D$. maydis, F. oxysporum, $S$. sclerotiorum, C. fimbriata, F. oxysporum f. sp. vasinfectum, and $P$. piricola. The results are summarized in Table 2, indicating that compounds 1, 2, 4, 8 and 9 displayed significant activity against D. maydis with MIC value of $25 \mu \mathrm{g} \mathrm{mL}{ }^{-1}$. Moreover, compound 1 also exhibited significant activity against other three fungi including $R$. cerealis, $F$. oxysporum and $P$. piricola, and compounds 4 and 9 against $R$. cerealis with MIC value of $25 \mu \mathrm{g}$ $\mathrm{mL}^{-1}$, respectively. Compound $\mathbf{5}$ only demonstrated significant activity against $P$. piricola with MIC value of $25 \mu \mathrm{g} \mathrm{mL}{ }^{-1}$. Compounds 3, 6 and 7 showed moderate or weak activity against selective strains. Besides, all isolates (1-9) were evaluated for their antibacterial activity against Gram-positive $(M$. luteus, S. aureus, B. megaterium, B. anthracis, B. paratyphosum B and drug resistant $S$. aureus) and Gram-negative (P. aeruginosa, E. coli and E. aerogenes) bacteria (Table 3). Compounds 1-3, 6, 8 and 9 exhibited significant activity against $M$. luteus, $S$. aureus, B. megaterium, B. anthracis, and B. paratyphosum B with MIC values of 25 and $12.5 \mu \mathrm{g} \mathrm{mL} \mathrm{m}^{-1}$, respectively. Compound 4 displayed significant activity against four Gram-positive bacteria including M. luteus, S. aureus, B. megaterium, and B. paratyphosum B with MIC value of $25 \mu \mathrm{g} \mathrm{mL}{ }^{-1}$, respectively. While compounds 5 and 7 exhibited antibacterial activity against $S$. aureus, B. megaterium, and B. paratyphosum B with MIC values of 25 and $12.5 \mu \mathrm{g} \mathrm{mL}{ }^{-1}$, respectively. In addition, only compounds
1, 4 and 9 showed moderate activity against drug resistant $S$. aureus with MIC value of $50 \mu \mathrm{g} \mathrm{mL} \mathrm{m}^{-1}$. All isolated compounds displayed moderate activity against three Gram-negative $(P$. aeruginosa, E. coli, and E. aerogenes) bacteria with MIC value of $50 \mu \mathrm{g} \mathrm{mL} \mathrm{L}^{-1}$.

\section{Conclusions}

In summary, we have reported the isolation, identification and biological study of nine compounds (1-9) including four new ones (1-4), seven of them belonging to prenylxanthones from the solid-substrate fermentation culture of Emericella sp. XL029. The occurrence of prenylxanthone derivatives from Emericella sp. XL029 is in agreement with the previous findings, ${ }^{8-14}$ indicating that the isolation of these compounds might be a useful chemotaxonomic marker of the Emericella genus. The results of preliminary anti-agricultural pathogenic fungal and antibacterial assays suggested that these isolated prenylxanthone derivatives showed moderate activity. Moreover, previous findings predicted that the fungal metabolites produced by endophytic fungi may be useful for the growth of the plant host. In other words, those fungal metabolites that may protect the fungal and the host from parasites, as well as other predators such as bacteria, fungi, and animals. ${ }^{25-30}$ Thus, these newly discovered fungal pigments might be presumed to act as phytoalexins occurring in endophytic fungi.

\section{Experimental section}

\section{General experimental procedures}

Melting points were measured on a SGW X-4A melting point apparatus and reported without corrections. Optical rotations were measured on an Autopol III automatic polarimeter (Rudolph Research Analytical). UV spectra were recorded with an Agilent spectrophotometer (Agilent Cary60). The IR spectra were recorded using a Bruker spectrophotometer (TENSOR-27). HR-ESI-MS spectra were recorded on a Bruker FTMS instrument (SolariX). Nuclear magnetic resonance (NMR) spectra were recorded on an Agilent DD2 (400 MHz) instrument. Silica gel 
(200-300 mesh, Qingdao Marine Chemical Factory, Qingdao, China) and Sephadex LH-20 (Pharmacia Biotech, Uppsala, Sweden) were used for column chromatography. Semipreparative HPLC separation was equipped with a NP7005C

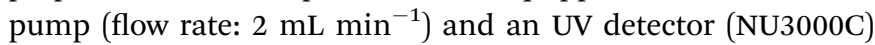
using a Dubhe ${ }^{\mathrm{TM}}$ C18 column $(250 \mathrm{~mm} \times 10 \mathrm{~mm}, 5 \mu \mathrm{m}$, Hanbang, Jiangsu, China). Single-crystal X-ray diffraction data was collected on a SuperNova, Dual, Eos CCD area detector diffractometer (Agilent, USA) with graphite monochromated Mo $\mathrm{K} \alpha$ radiation $(\lambda=0.71073 \AA)$.

\section{Fungal material}

The culture of Emericella sp. XL029 was isolated from the leaves of Panax notoginseng collected from Shijiazhuang, Hebei Province, People's Republic of China in September 2015. The isolate was identified based on sequence (GenBank Accession No. KY350849) analysis of the ITS region of the rDNA. All tested bacterial and fungal strains for biological studies were obtained as gifts from Associated Professor Fei Cao at College of Pharmaceutical Sciences, Hebei University.

\section{Fermentation, extraction, and isolation}

The fungal strain was cultured on potato dextrose agar at $28{ }^{\circ} \mathrm{C}$ for 7 days. Then, cut agar plugs into small pieces (about $0.5 \times$ $0.5 \times 0.5 \mathrm{~cm}^{3}$ ) under aseptic conditions, and 5 pieces were transferred into ten Erlenmeyer flasks $(250 \mathrm{~mL})$ containing 100 mL PYG media ( $\mathrm{L}^{-1}$ : peptone $10 \mathrm{~g}$, yeast extract $10 \mathrm{~g}$, glucose 10 $\mathrm{g}$ ), and incubated on a rotary shaker at $160 \mathrm{rpm}$ and $28{ }^{\circ} \mathrm{C}$ for 7 days to prepare the seed culture. The scale-up fermentation was carried out in 100 Erlenmeyer flasks $(500 \mathrm{~mL})$ each containing $60 \mathrm{~g}$ of rice and $90 \mathrm{~mL}$ of distilled water and $20 \mathrm{~g} \mathrm{~L}^{-1}$ glucose, $20 \mathrm{~g} \mathrm{~L}^{-1}$ sea salt. Each flask was inoculated with $5.0 \mathrm{~mL}$ of the spore inoculum and incubated at $28{ }^{\circ} \mathrm{C}$ for 40 days.

The fermented material was extracted with $\mathrm{MeOH}(3 \times 10 \mathrm{~L})$ at room temperature, and the organic solvent was evaporated to dryness under vacuum to afford a brown residue, which was then suspended in water and extracted three times with an equal volume of EtOAc to yield $102 \mathrm{~g}$ of crude extract. The crude extract was subjected to CC (column chromatography over $\mathrm{SiO}_{2}$ with a petroleum ether/acetone gradient system $10: 0,9: 1$, $8: 2,7: 3,6: 4$, and $1: 1$ ) to yield nine fractions, Fr. A-I. Fraction $\mathrm{C}(0.8 \mathrm{~g})$ was further purified by Sephadex $\mathrm{LH}-20\left(\mathrm{CHCl}_{3} /\right.$ $\mathrm{MeOH}, 1: 1)$ and silica gel CC with petroleum ether/EtOAc $(15: 1)$ to afford compound $7(12.0 \mathrm{mg})$. Fraction D $(1.0 \mathrm{~g})$ was subjected to repeated chromatography over silica gel (petroleum ether/EtOAc, $12: 1$ ) to yield four fractions D1-D4. Fraction D4 $(269.0 \mathrm{mg})$ was further purified by Sephadex $\mathrm{LH}-20\left(\mathrm{CHCl}_{3} /\right.$ $\mathrm{MeOH}, 1: 1)$ and semi-preparative HPLC eluting with $\mathrm{MeOH}-$ $\mathrm{H}_{2} \mathrm{O}$ (90:10) to afford compounds 1 (13.0 mg), 3 (11.0 mg), and 6 (4.0 mg). Fraction $\mathrm{G}(1.7 \mathrm{~g})$ was fractionated by Sephadex $\mathrm{LH}$ $20\left(\mathrm{CHCl}_{3} / \mathrm{MeOH}, 1: 1\right)$ to give three fractions (G1-G3). Fraction G1 was further purified by semi-preparative HPLC eluting with $\mathrm{MeOH}-\mathrm{H}_{2} \mathrm{O}(90: 10)$ to afford compounds 4 (9.0 mg) and 5 (20.0 $\mathrm{mg}$ ), and fraction G3 was subjected to CC on silica gel (petroleum ether-acetone, $6: 1)$ to obtain compound 8 (6.0 mg). Compound $2(12.0 \mathrm{mg})$ was obtained from fraction $\mathrm{H}(1.3 \mathrm{~g})$ after repeated chromatography over silica gel (petroleum ether/ EtOAc, $5: 1)$. Compound 9 (12.0 $\mathrm{mg}$ ) was obtained from fraction I $(1.03 \mathrm{~g})$ after repeated chromatography over silica gel (chloroform/methanol, $15: 1$ ).

14-Hydroxyltajixanthone (1). Yellow powder; mp 184-185 ${ }^{\circ} \mathrm{C}$; $[\alpha]_{\mathrm{D}}^{24}-59\left(c 0.183, \mathrm{CHCl}_{3}\right) ; \mathrm{UV}(\mathrm{MeOH}) \lambda_{\max }(\log \varepsilon) 387$ (3.81), 253 (4.64), 230 (4.82), 203 (4.99) nm; IR (KBr) $\nu_{\max } 3446(\mathrm{OH})$, 2959, 2923, 1643 (C=O), 1602, 1576, 1475, 1431, 1244, 1125, 1021, 953, 905, $823 \mathrm{~cm}^{-1}$; see Table 1 for ${ }^{1} \mathrm{H}$ NMR $\left(\mathrm{CDCl}_{3}, 400\right.$ $\mathrm{MHz})$ and ${ }^{13} \mathrm{C} \mathrm{NMR}\left(\mathrm{CDCl}_{3}, 100 \mathrm{MHz}\right)$; negative HRESIMS [M $\mathrm{H}]^{-} m / z$ 437.1586 (calcd for $\mathrm{C}_{25} \mathrm{H}_{25} \mathrm{O}_{7}, 437.1606$ ).

14-Hydroxyltajixanthone hydrate (2). Yellow powder; $\mathrm{mp}$ 191-192 ${ }^{\circ} \mathrm{C} ;[\alpha]_{\mathrm{D}}^{24}-40\left(c 0.1, \mathrm{CHCl}_{3}\right) ; \mathrm{UV}(\mathrm{MeOH}) \lambda_{\max }(\log \varepsilon) 390$ (3.77), 270 (4.43), 240 (4.39), 205 (4.62) nm; IR (KBr) $\nu_{\max } 3423$ $(\mathrm{OH}), 2922,2853,1645(\mathrm{C}=\mathrm{O}), 1473,1430,1383,1243,1050$, $823,486 \mathrm{~cm}^{-1}$; see Table 1 for ${ }^{1} \mathrm{H}$ NMR $\left(\mathrm{CDCl}_{3}, 400 \mathrm{MHz}\right)$ and ${ }^{13} \mathrm{C} \mathrm{NMR}\left(\mathrm{CDCl}_{3}, 100 \mathrm{MHz}\right)$; positive HRESIMS $[\mathrm{M}+\mathrm{Na}]^{+} \mathrm{m} / z$ 479.16835 (calcd for $\mathrm{C}_{25} \mathrm{H}_{28} \mathrm{O}_{8} \mathrm{Na}, 479.16764$ ).

14-Hydroxyl-15-chlorotajixanthone hydrate (3). Yellow powder; mp $178-179{ }^{\circ} \mathrm{C}$; $[\alpha]_{\mathrm{D}}^{24}-53\left(c 0.167, \mathrm{CHCl}_{3}\right)$; UV $(\mathrm{MeOH})$ $\lambda_{\max }(\log \varepsilon) 388$ (3.65), 273 (4.39), 235 (4.40), 203 (4.78), 201 (4.81) nm; IR (KBr) $\nu_{\max } 3519(\mathrm{OH}), 2922,2853,1641(\mathrm{C}=\mathrm{O})$, 1601, 1473, 1432, 1389, 1240, 1050, 901, $749 \mathrm{~cm}^{-1}$; see Table 1 for ${ }^{1} \mathrm{H} \mathrm{NMR}\left(\mathrm{CDCl}_{3}, 400 \mathrm{MHz}\right)$ and ${ }^{13} \mathrm{C} \mathrm{NMR}\left(\mathrm{CDCl}_{3}, 100 \mathrm{MHz}\right)$; negative HRESIMS $[\mathrm{M}-\mathrm{H}]^{-} \mathrm{m} / z \quad 473.13643$ (calcd for $\left.\mathrm{C}_{25} \mathrm{H}_{27} \mathrm{ClO}_{7}, 473.13725\right)$.

Epitajixanthone hydrate (4). Yellow needle crystals; $\mathrm{mp}$ $176{ }^{\circ} \mathrm{C} ;[\alpha]_{\mathrm{D}}^{24}+62\left(c \quad 0.1, \mathrm{CHCl}_{3}\right) ; \mathrm{UV}(\mathrm{MeOH}) \lambda_{\max }(\log \varepsilon) 390$ (3.80), 273 (4.57), 235 (4.54), 203 (4.80), 201 (4.79) nm; IR (KBr) $\nu_{\max } 3352(\mathrm{OH}), 2923,2854,1642(\mathrm{C}=\mathrm{O}), 1572,1478,1349,1246$, 1119, 1079, 1022, 818, $730 \mathrm{~cm}^{-1}$; see Table 1 for ${ }^{1} \mathrm{H}$ NMR $\left(\mathrm{CDCl}_{3}\right.$, $400 \mathrm{MHz})$ and ${ }^{13} \mathrm{C} \mathrm{NMR}\left(\mathrm{CDCl}_{3}, 100 \mathrm{MHz}\right)$; positive HRESIMS $[\mathrm{M}+\mathrm{Na}]^{+} m / z 463.17202$ (calcd for $\mathrm{C}_{25} \mathrm{H}_{28} \mathrm{O}_{7} \mathrm{Na}, 463.17272$ ).

\section{X-ray crystallography of compound 4}

A yellow needle crystal of compound 4 (CCDC: $1525724 \dagger$ ) was obtained from an $n$-hexane/acetone $(2: 1)$ solution. The X-ray crystallographic data of 4: $\mathrm{C}_{25} \mathrm{H}_{28} \mathrm{O}_{7}$, monoclinic, space group:

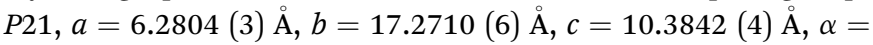
$90^{\circ}, \beta=101.759(4)^{\circ}, \gamma=90^{\circ}, V=1102.72(8) \AA^{3}, Z=2, D_{\text {calcd }}=$ $1.327 \mathrm{~g} \mathrm{~cm}^{-3}, \mathrm{w} R 1(I>2 \sigma(I))=0.0478, \mathrm{w} R 2=0.1072$. Crystal size, $0.40 \times 0.25 \times 0.10 \mathrm{~mm}^{3}$. Flack parameter, $0.5(6)$.

\section{Antifungal assay}

Antifungal bioassays were conducted as described previously. ${ }^{\mathbf{1 5}}$ The eight agricultural pathogenic fungi, namely, Rhizoctonia solani, Rhizoctonia cerealis, Drechslera maydis, Fusarium oxysporum, Sclerotinia sclerotiorum, Ceratocystis fimbriata, Fusarium oxysporum f. sp. vasinfectum, and Physalospora piricola, were grown on PDA. Targeted microbes (3-4 colonies) were prepared from broth culture $\left(28{ }^{\circ} \mathrm{C}\right.$ for $\left.72 \mathrm{~h}\right)$, and the final spore suspensions of fungi (in PDB) were $10^{4}$ mycelia fragments per $\mathrm{mL}$. Test samples $\left(1 \mathrm{mg} \mathrm{mL} \mathrm{m}^{-1}\right.$ as stock solution in DMSO and serial dilutions) were transferred to 96 -well clear plate in triplicate, and the suspension of the test organisms were added to each well, achieving a final volume of $100 \mu \mathrm{L}$ (ketoconazole was 
used as the positive control). After incubation, the minimum inhibitory concentration (MIC) was defined as the lowest test concentration that completely inhibited the growth of the test organisms.

\section{Antibacterial assay}

All isolated compounds were evaluated for their antibacterial activity against Gram-positive (Micrococcus luteus, Staphylococcus aureus, Bacillus megaterium, Bacillus anthracis, Bacterium paratyphosum B and drug resistant Staphylococcus aureus) and Gram-negative (Pseudomonas aeruginosa, Escherichia coli, and Enterobacter aerogenes) bacteria. They were grown in liquid LB medium (yeast extract $5 \mathrm{~g} \mathrm{~L}^{-1}$, peptone $10 \mathrm{~g} \mathrm{~L}^{-1}, \mathrm{NaCl} 10 \mathrm{~g} \mathrm{~L}^{-1}$, $\mathrm{PH}=7.4$ ) overnight at $37{ }^{\circ} \mathrm{C}$, and the diluted bacterial suspension $\left(10^{6} \mathrm{CFU}\right.$ per milliliter) was ready for detection. The minimum inhibitory concentrations (MIC) of samples and positive control were determined in sterile 96-well plates by the modified broth dilution test. ${ }^{16}$ All wells were filled with $90 \mu \mathrm{L}$ of bacterial suspension containing $10^{6} \mathrm{CFU}$ per milliliter. Test samples $(10 \mu \mathrm{L})$ with their different concentrations were added into each well. Medium containing 1\% DMSO was used as a negative control, ciprofloxacin was used as the positive control. The final concentrations of ciprofloxacin and test compounds were 100, 50, 25, 12.5, 6.25, 3.12, 1.56, $0.78 \mu \mathrm{g} \mathrm{mL}^{-1}$ in medium. After incubation, the minimum inhibitory concentration (MIC) was defined as the lowest test concentration that completely inhibited the growth of the test organisms.

\section{Acknowledgements}

We thank the Fundamental Research Funds for the Central Universities (No. 0903005203401), the Start-up Fund for the "Hundred Young-Talent Scheme" Professorship provided by Chongqing University in China (No. 0236011104424).

\section{Notes and references}

1 H. R. El-Seedi, D. M. El-Ghorab, M. A. El-Barbary, M. F. Zayed, U. Göransson, S. Larsson and R. Verpoorte, Curr. Med. Chem., 2009, 16, 2581-2626.

2 K. S. Masters and S. Bräse, Chem. Rev., 2012, 112, 3717-3776.

3 H. R. El-Seedi, M. A. El-Barbary, D. M. El-Ghorab, L. Bohlin, A. K. Borg-Karlson, U. Göransson and R. Verpoorte, Curr. Med. Chem., 2010, 17, 854-901.

4 S. Genovese, S. Fiorito, V. A. Taddeo and F. Epifano, Drug Discovery Today, 2016, 21, 1814-1819.

5 S. Gouda, G. Das, S. K. Sen, H. S. Shin and J. K. Patra, Front Microbiol., 2016, 7, 1538-1545.

6 H. Long, Z. Cheng, W. Huang, Q. Wu, X. Li, J. Cui, P. Proksch and W. Lin, Org. Lett., 2016, 18, 4678-4681.

7 H. Zhou, X. Sun, N. Li, Q. Che, T. Zhu, Q. Gu and D. Li, Org. Lett., 2016, 18, 4670-4673.

8 J. Liangsakul, S. Srisurichan and S. Pornpakakul, Steroids, 2016, 106, 78-85.
9 Q. Wu, C. Wu, H. Long, R. Chen, D. Liu, P. Proksch, P. Guo and W. Lin, J. Nat. Prod., 2015, 78, 2461-2470.

10 M. Fredimoses, X. Zhou, X. Lin, X. Tian, W. Ai, J. Wang, S. Liao, J. Liu, B. Yang, X. Yang and Y. Liu, Mar. Drugs, 2014, 12, 3190-3202.

11 J. Malmstrøm, C. Christophersen, A. F. Barrero, J. E. Oltra, J. Justicia and A. Rosales, J. Nat. Prod., 2002, 65, 364-367.

12 M. Figueroa, M. C. González, R. Rodríguez-Sotres, A. SosaPeinado, M. González-Andrade, C. M. Cerda-García-Rojas and R. Mata, Bioorg. Med. Chem., 2009, 17, 2167-2174.

13 P. Moosophon, S. Kanokmedhakul, K. Kanokmedhakul and K. Soytong, J. Nat. Prod., 2009, 72, 1442-1446.

14 S. Pornpakakul, J. Liangsakul, N. Ngamrojanavanich, S. Roengsumran, P. Sihanonth, J. Piapukiew, E. Sangvichien, S. Puthong and A. Petsom, Arch. Pharmacal Res., 2006, 29, 140-144.

15 D. T. Wicklow, B. K. Joshi, W. R. Gamble, J. B. Gloer and P. F. Dowd, Appl. Environ. Microbiol., 1998, 64, 4482-4484.

16 R. D. Langfielda, F. J. Scaranob, M. E. Heitzmana, M. Kondoa, G. B. Hammonda and C. C. Netoa, J. Ethnopharmacol., 2004, 94, 279-281.

17 K. K. Chexal, C. Fouweather, J. S. E. Holker, T. J. Simpson and K. Young, J. Chem. Soc., Perkin Trans., 1974, 1, 15841593.

18 K. K. Chexal, J. S. Holker and T. J. Simpson, J. Chem. Soc., Perkin Trans., 1975, 6, 549-554.

19 M. Ishida, T. Hamasaki, Y. Hatsuda, K. Fukuyama, T. Tsukihara and Y. Katsube, Agr. Biol. Chem., 1976, 40, 1051-1052.

20 H. Fujimoto, T. Fujimaki, E. Okuyama and M. Yamazaki, Chem. Pharm. Bull., 1999, 47, 1426-1432.

21 O. I. Zhuravleva, A. Ssh, V. A. Denisenko, S. P. Ermakova, N. N. Slinkina, P. S. Dmitrenok and N. Y. Kim, Phytochemistry, 2012, 80, 123-131.

22 S. A. Ahmed, E. Bardshiri, C. R. Mcintyre and T. J. Simpson, Aust. J. Chem., 1992, 23, 238.

23 B. S. Antia, T. Aree, C. Kasettrathat, S. Wiyakrutta, O. D. Ekpa, U. J. Ekpe, C. Mahidol, S. Ruchirawat and P. Kittakoop, Phytochemistry, 2011, 72, 816-820.

24 S. Sureram, S. Wiyakrutta, N. Ngamrojanavanich, C. Mahidol, S. Ruchirawat and P. Kittakoop, Planta Med., 2012, 78, 582-588.

25 H. Li, J. Wei, S. Y. Pan, J. M. Gao and J. M. Tian, Nat. Prod. Res., 2014, 28, 2358-2361.

26 Y. Yuan, J. M. Tian, J. Xiao, Q. Shao and J. M. Gao, Nat. Prod. Res., 2014, 28, 278-281.

27 X. J. Li, Q. Zhang, A. L. Zhang and J. M. Gao, J. Agric. Food Chem., 2012, 60, 3424-3431.

28 J. M. Gao, S. X. Yang and J. C. Qin, Chem. Rev., 2013, 113, 4755.

29 J. Xiao, Q. Zhang, Y. Q. Gao, X. W. Shi and J. M. Gao, Nat. Prod. Res., 2014, 28, 1388-1392.

30 C. Porntep, W. Suthep, A. Thammarat, S. Nongluksna, N. Nattaya, M. Chulabhorn, R. Somsak and K. Prasat, Chem.-Eur. J., 2010, 16, 11178-11185. 